\title{
Physiological maturation of cowpea seeds ${ }^{1}$
}

\author{
Narjara Walessa Nogueira ${ }^{2 *}$, Rômulo Magno Oliveira de Freitas², \\ Salvador Barros Torres ${ }^{2}$, Caio César Pereira Leal ${ }^{2}$
}

\begin{abstract}
The seed maturation process is genetically controlled and involves an arranged sequence of morphological and physiological changes extending from fertilization to its total independence from the mother-plant. These changes also include a set of preparatory phases for the germination process, which are characterized for the synthesis and accumulation of nutrient reserves. Thereby, this study was developed aiming at assessing development and physiological quality of cowpea seeds during maturation process. To this, the cowpea pods of cultivar BRS-Guariba were harvested from the tenth day after anthesis (DAA) until the twenty sixth DAA, with four days intervals. Immediately after each harvest, seeds were manually extracted from the pods and then subjected to the following determinations: moisture content, first count of germination, final germination percentage, length of shoots and roots, hypocotyl diameter, and seedling dry mass. The experiment was conducted in a completely randomized design, with five treatments (DAA), and four replications to each treatment. Results have shown that cowpea seeds have fairly fast physiological maturation, and that seeds harvested between 14 and 18 DAA have better vigor as well as higher germination rates; thus the harvest performed during this period does not cause damages to seeds.
\end{abstract}

Index terms: Vigna unguiculata L., physiological quality, vigor.

\section{Maturação fisiológica de sementes de feijão-caupi}

\begin{abstract}
RESUMO - A maturação da semente é controlada geneticamente, envolvendo uma sequência ordenada de alterações verificadas a partir da fecundação até que se tornem independentes da planta-mãe. Essas alterações compreendem um conjunto de etapas que preparam para o sucesso da futura germinação, caracterizada pela síntese e acúmulo de reservas. Dessa forma, este estudo teve por objetivo avaliar o desenvolvimento e qualidade fisiológica de sementes de feijão-caupi durante o processo de maturação. Para isso, vagens da cultivar BRS-Guariba de feijão-caupi foram colhidas a partir do décimo dia após a antese (DAA) até o vigésimo sexto DAA, com intervalos de quatro dias. Após cada coleta, as sementes foram manualmente extraídas das vagens e submetidas às seguintes determinações: grau de umidade, primeira contagem de germinação, porcentagem final de germinação, comprimento de parte aérea e raízes, diâmetro do hipocótilo e massa seca das plântulas. O experimento foi conduzido em delineamento experimental inteiramente casualizado, com cinco tratamentos (DAA) e quatro repetições cada. As sementes de feijão-caupi apresentam maturação fisiológica bastante rápida e aquelas colhidas entre 14 e 18 DAA têm melhor vigor e maior porcentagem de germinação; assim, colheita deve ser realizada durante esse período, pois não causa danos às sementes.
\end{abstract}

Termos para indexação: Vigna unguiculata L., qualidade fisiológica, vigor.

\section{Introduction}

The Northeast Brazil is a tropical region, which has about 1.6 million square kilometers of areas with semi-arid climate, where more than 30 million people live, and where there is predominance of rainfed agriculture using subsistence crops as the cowpea [Vigna unguiculata (L.) Walp.]. This crop has a significant socioeconomic importance to the population of the Northeast Region, since it is used both as food supplement as well as for the establishment of hand labor in the field, and is also the main component of the agricultural production of the northeastern farmers (Dutra et al., 2007; Bezerra et al., 2008; Rocha et al., 2009; Silva et al., 2010).

Although such crop has a broad adaptation to different growing conditions, the fields cropped with cowpea still have low productivity, with a world mean productivity of $370 \mathrm{~kg} \cdot \mathrm{ha}^{-1}$ (FAO, 2009). Nevertheless, Brazil annually produces about 480 thousand metric tons of cowpea, grown on 1.3 million

${ }^{1}$ Submitted on 07/13/2014. Accepted for publication on 08/19/2014.

${ }^{2}$ Laboratório de Análise de Sementes, Departamento de Fitotecnia, UFERSA, 59625-900 - Mossoró, RN, Brasil.

*Corresponding author < narjarawalessa@yahoo.com.br>

Journal of Seed Science, v.36, n.3, p.312-317, 2014 
hectares, with an approximate mean productivity of only $360 \mathrm{~kg} \cdot \mathrm{ha}^{-1}$. Such low productivity is mainly due to the low technological level of producers of this leguminous and the use of seeds with low physiological quality in their cowpea crops (Freire-Filho et al., 2005; Cardoso and Ribeiro, 2006).

The seed is the main input in production systems of the major crops; and the high physiological quality of these seeds is the main factor responsible by the initial stand and by vigor of plants in the field, and consequently by the high crop productivity. However, it is essential that seed has reached the full physiological maturity before being harvested to be able to express all its germination potential. Hence, obtaining high physiological quality seeds will depend on the ideal harvest moment; once such moment should correspond to that in which the physiological maturity is reached and the seed has the maximum dry mass accumulation, high vigor, and high potential for germination (Carvalho and Nakagawa, 2000).

The seed maturation process is genetically controlled and involves an arranged sequence of morphological and physiological changes extending from fertilization to its total independence from the mother-plant. These changes also include a set of preparatory phases for the germination process, which are characterized for the synthesis and accumulation of nutrient reserves (Marcos-Filho, 2005).

The literature on this subject presents several studies on the influence of the physiological maturity, as well as seed quality on productivity of several important crops. As examples, it can be cited the studies performed by David et al. (2003), Faria et al. (2005), and Araújo et al. (2006) with seeds of maize (Zea mays L.); Botelho et al. (2010) and Bolina (2012) with seeds of common bean (Phaseolus vulgaris L.) and Eskandari (2012) with seeds of southern pea (Vigna sinensis (L.). However, information on physiological maturity and ideal harvest time of cowpea seeds are still scarce, especially for the cv. BRS-Guariba, which is widely grown in the crop fields of Northeast Region of Brazil.

Thereby, this study was developed aiming at assessing development and physiological quality of cowpea seeds during maturation process.

\section{Material and Methods}

Seeds of cv. BRS-Guariba of cowpea used in this study were produced in a seed production field installed in the didactic vegetable garden of the Department of Plant Sciences, Federal Rural University of the Semi-Arid, located in the municipality of Mossoró, state of Rio Grande do Norte, Northeastern Region of Brazil, and collected between September and December, 2011. Municipality of Mossoró is located between the geographic coordinates $5^{\circ} 11^{\prime} \mathrm{S}$ and $37^{\circ} 20^{\prime} \mathrm{W}$, at an altitude of $18 \mathrm{~m}$.

The Figure 1 shows the climatological data (air temperature and relative humidity) observed during the experiment. During the research there was only one rain of 5 $\mathrm{mm}$ at 31 days after sowing (DAS).

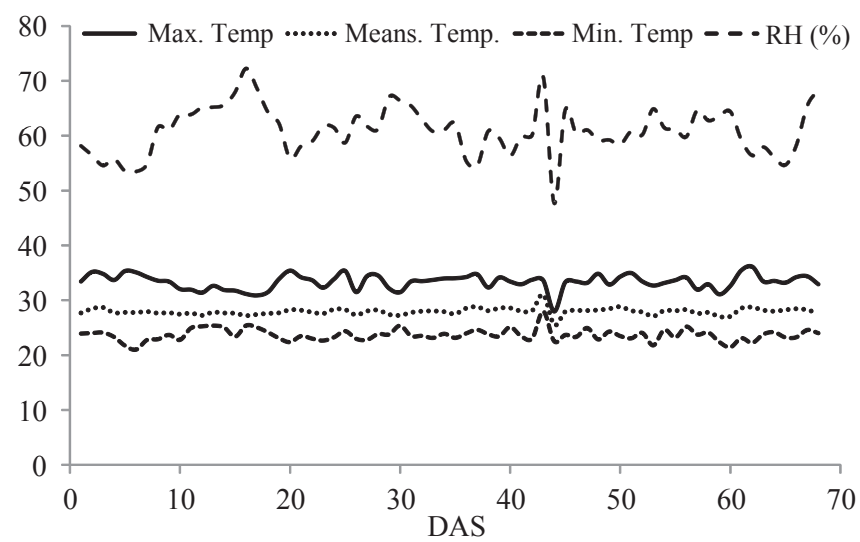

Figure 1. Temperatures minimal, means and maximal $\left({ }^{\circ} \mathrm{C}\right)$ and relative humidity $(\mathrm{RH})$ recorded at the Meteorological.

The soil samples collected within the experimental area were subjected to chemical analysis, which revealed the following fertility level of soil area: $\mathrm{pH}$ (water) $=6.1$; organic matter content $=10.1$ g.kg ${ }^{-1} ; \mathrm{P}=220.4 \mathrm{mg} \cdot \mathrm{dm}^{-3} ; \mathrm{K}^{+}=157.3$ mg. $\mathrm{dm}^{-3} ; \mathrm{Ca}^{2+}=3.65$ cmolc. $\mathrm{dm}^{-3} ; \mathrm{Mg}^{2+}=1.0 \mathrm{cmolc} . \mathrm{dm}^{-3} ;$ and $\mathrm{Al}^{3+}=0.15$ cmolc. $\mathrm{dm}^{-3}$.

The soil of experimental area was tilled with a single plowing followed by two disking; and the sowing was performed with a spacing of $0.3 \mathrm{~m} \times 0.5 \mathrm{~m}$, with aid of a manually operated seeder for the simultaneous procedures of seeding and fertilizer application, set to sow from two to four seeds in each of the planting pits together with an adequate fertilizer amount. On the tenth day after sowing a thinning was made on the plants emerged in each of the planting pits; thereby keeping only one plant per planting pit.

Water requirement was daily monitored by using a set of soil tensiometers installed at $20 \mathrm{~cm}$ deep; and whenever needed irrigation was applied by a dripping system, with flow regulated to $1.7 \mathrm{~L} \cdot \mathrm{h}^{-1}$. According to the need, all other cultural practices were also performed.

During flowering, which has approximately started 35 DAS, and throughout the crop cycle, always in the morning period, the blooming flowers were marked with colored ribbons to identify the anthesis date. Harvesting of pods was performed according to the harvesting periods pre-established to the treatments $(10$, 
14, 18, 22 and 26 DAA); and soon after harvesting, such pods were taken to the Seed Testing Laboratory, where seeds were immediately extracted from the pods.

The seed quality was assessed by the following tests: Seed moisture content - this test was performed with two seed subsamples, containing 10 grams each, to each treatment. The moisture content of the seeds was determined by the oven method, at $105 \pm 3{ }^{\circ} \mathrm{C}$, for $24 \mathrm{~h}$ (Brasil, 2009), and results were expressed as percentage (wet basis); Germination - was conducted with four replications, containing 50 seeds each, to each treatment. To this, the seeds were evenly distributed onto two towel paper sheets, moistened with distilled water, in a volume equivalent to 2.5 times the weight of the dry substrate, and covered with another sheet of same paper likewise moistened. Thereupon, the set (seed + towel paper) was made into rolls, which were then placed in a vertical position into a seed germinator, set at $30{ }^{\circ} \mathrm{C}$ constant temperature, and 8/14 h (L/D) photoperiod. Assessments were performed at the eighth DAS by counting the number of normal emerged seedlings; and results were expressed on percentage germination (Brasil, 2009); First count of germination - the test was performed during the standard germination test; but, percentage of normal emerged seedlings was determined at the fifth DAS (Brasil, 2009); Germination speed - this test was also conducted during germination test; however, the normal emerged seedlings were daily counted until the eighth DAS; and the mean number of days for germination was computed by the equation proposed by Edmond and Drapala (1958).

To the normal emerged seedlings were also carried out the following determinations: Root length - for this determination, the normal emerged seedlings were measured from the base of hypocotyl until the tip of main root, with aid of a ruler graduated in centimeters. Such determination was performed on all normal emerged seedlings, in all replications of all treatments; and results were expressed as cm.seedling ${ }^{-1}$; Shoot length - on this determination the normal emerged seedlings were measured from the hypocotyl base to the apex of the seedling, also with aid of a ruler graduated in centimeters. This determination was also performed on all normal seedlings, in all replications of all treatments; and results were also expressed on cm.seedling ${ }^{-1}$; Hypocotyl diameter - these data were obtained by measuring the hypocotyl basis of the seedling at soil line, with aid of a digital caliper, and carried out on all normal emerged seedlings, in all replicates of each treatment. Results were expressed as mm.seedling ${ }^{-1}$; and Seedling dry mass - for this determination, all the normal emerged seedlings at the experimental unit were placed into a forced hot air circulating drying oven, set at $65^{\circ} \mathrm{C}$, until reach constant weight and immediately weighed on an analytical balance with $0.001 \mathrm{~g}$ precision. Results were expressed as g.seedling ${ }^{-1}$.

The experiment was carried out on a completely randomized design, with five treatments (10, 14, 18, 22 and 26 DAA), and four replicates per treatment. Data were previously subjected to exploratory analysis to assess the assumptions of normality of residuals, homogeneity of variance of treatments, and additivity of the model, before applying the ANOVA. The variables analyzed were then subjected to regression analysis, and adjustments of the regression polynomial curves were computed as function of the age of pods.

\section{Results and Discussion}

Results obtained in this experiment showed that, depending on the harvesting date of the cowpea pods there were significant differences $(p<0.01)$ between the means achieved for germination, first count of germination, and germination speed as well as for length of shoots and roots, hypocotyl diameter, and seedling dry mass.

The mean values obtained for seed moisture content presented a decreasing behavior over time; (Figure 1A); from the first harvest date (10 DAA - 87.2\%) there was a sharp drop on mean values until the second (14 DAA - 53.6\%) and third (18 DAA - 14\%) harvest dates, and after that date the values slowly decreased until last date assessed (26 DAA - $12 \%$ ). Thus, the higher moisture content, and hence the greater accumulation of dry seeds, occurred in the last harvest, at 26 DAA.

Gradual reduction on moisture content throughout seed maturation process has also been observed in mayze (David et al., 2003; Faria et al., 2005; Araújo et al., 2006), common bean (Botelho et al., 2010; Bolina, 2012) and Southern pea (Eskandari, 2012).

The polynomial linear regression curve presented on Figure $2 \mathrm{~B}$ shows that the cowpea seeds harvested at 10 DAA did not germinate and germination percentage of seeds harvested at 14 DAA reached $96 \%$. It also shows that, from the third harvest (18 DAA - 92\%) until the last harvest, the germination percentage remained high and stable with mean percentages of $95 \%$ and $93 \%$, respectively for the seeds harvested at 22 DAA and 26 DAA.

The highest percentage of germination was observed between the second and third collection (14 DAA and 18 DAA) in the same period, also were observed the highest values for the first count of germination (Figure 2C), root length (Figure 3A), shoot length (Figure 3B) and seedling dry mass (Figure 3D).

The higher vigor, indicated by the higher percentage and first count of germination, greater roots and shoots lengths and increased seedling dry matter obtained between 14 and 18 DAA coincides with the point of highest physiological seed quality, the point of physiological maturity. 

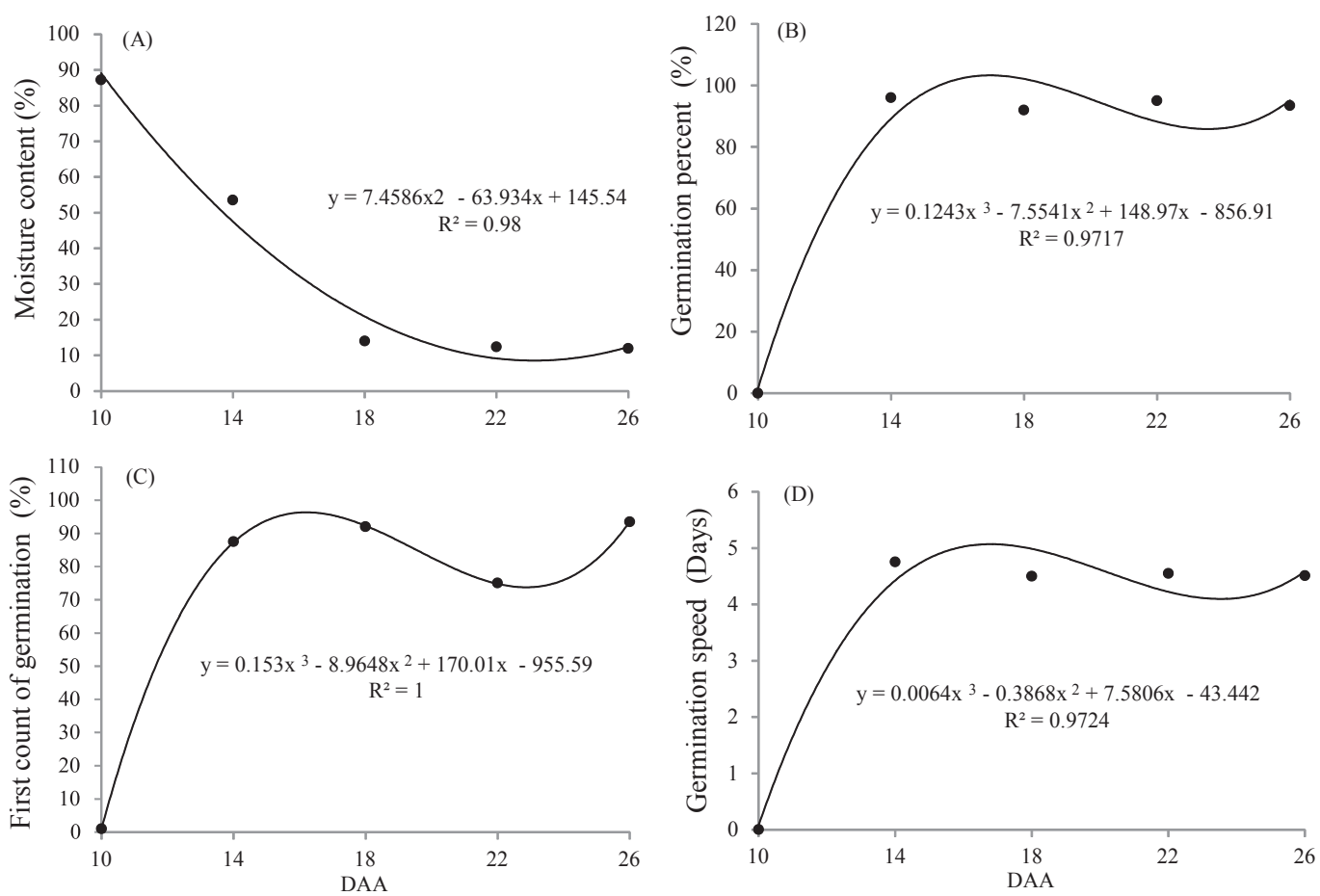

Figure 2. Graphical representation of the polynomial linear regression curves plotted to mean values obtained for moisture content (A), germination percentage (B), first count of germination (C), germination speed (D) of cowpea seeds, cv. BRS-Guariba, harvested at different times (days after anthesis-DAA).
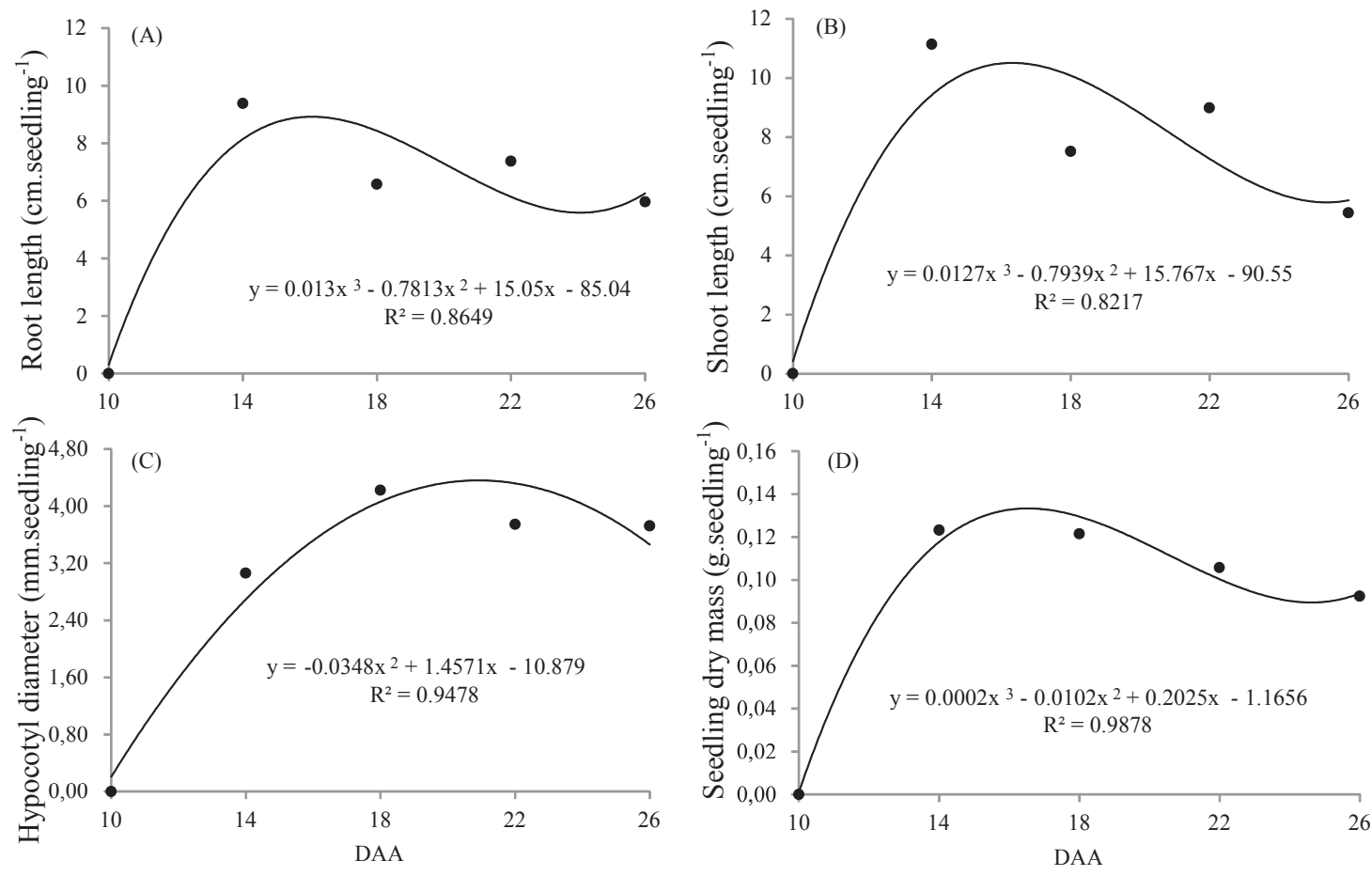

Figure 3. Graphical representation of the polynomial linear regression curves plotted to mean values obtained for root length (A), shoot length (B), hypocotyl diameter (C) and dry mass (D) of cowpea seedlings, cv. BRS-Guariba, as function of days after anthesis (DAA) in which seeds were harvested. 
The seeds harvested at 10 DAA did not germinate probably due to presence of inhibitors, such as abscisic acid, which according Kermode (2005), when in high concentrations in the seed may prevent its early germination; thus favoring both the reserves accumulation as well as the embryo maturation. Similarly, Braga-Júnior (2009) in his work with castor bean seeds has verified that, to the seeds harvested at 10 DAA the germination was also nil, starting only after 21 DAA. Moreover, this author also observed that seed germination ranged between $86 \%$ and $91 \%$, when seeds were harvested at 28 DAA, reaching a maximum value of $91.2 \%$ at 56 DAA.

Stabilization of germination percentage observed in this study on cowpea seeds has been also observed by David et al. (2003) with popcorn seeds [Zea mays L. var. everta (Sturtev.) L. H. Bailey], obtaining $77 \%$ germination for the seeds harvested at 30 DAA, and $99 \%$ germination for the seeds harvested at 44 DAA.

From the maturity point the germination percentage remained stable until the end of the studied period (93 DAA). Likewise, Araújo et al. (2006), in a study on physiological maturity of seeds of sweet corn [Zea mays L. var. saccharata (Sturtev.) L. H. Bailey] found that the seeds harvested at 27 DAA had germination of $66 \%$ reaching $93 \%$ only when harvested at 34 DAA; from this maturation phase the seed germination remained stable.

The values obtained for first count of the germination test $(65 \%)$ and of the standard germination test $(80 \%)$ of the seeds harvested between 14 DAA and 26 DAA (Figures 2B and $2 \mathrm{C}$, respectively) were higher than those values obtained by Teixeira et al. (2010) to this same cowpea cultivar.

The polynomial linear regression curve plotted with mean of the values obtained for hypocotyl diameter shows that there was a sharp increase until 18 DAA $\left(4.22 \mathrm{~cm}\right.$.seedling $\left.{ }^{-1}\right)$; from this harvesting date, there was a slowly decreased (3.74 $\mathrm{cm}$. seedling $^{-1}$ at $22 \mathrm{DAA}$ ), and afterwards remained stable until the last assessment, which was performed at 26 DAA (3.72 cm.seedling ${ }^{-1}$ ) (Figure 3C).

\section{Conclusions}

Seeds of cowpea cv. BRS-Guariba only reach physiological maturity at 14 days after anthesis (DAA).

The ideal point of physiological maturity of the seeds of $\mathrm{cv}$. BRS-Guariba of cowpea is situated between 14 and 18 DAA.

The seeds of cowpea of cv. BRS Guariba can be harvested between 14 and 18 DAA without damage to their vigor, for it is during this period that physiological maturation of the seed reaches their maximum and hence the maximum germination potential.

\section{References}

ARAUJO, E. F.; ARAUJO, R. F.; SOFIATTI, V.; SILVA, R. F. Maturação de sementes de milho-doce - Grupo super doce. Revista Brasileira de Sementes, v.28, n.2, p. 69-76, 2006. http://www.scielo.br/pdf/rbs/v28n2/a09v28n2

BEZERRA, A. A. C.; TÁVORA, F. J. A. F.; FREIRE FILHO, F. R.; RIBEIRO, V. Q. Morfologia e produção de grãos em linhagens modernas de feijão-caupi submetidas a diferentes densidades populacionais. Revista de Biologia e Ciências da Terra, v.8, n.1, p.85-93, 2008. http://www.redalyc. org/articulo.oa? $\mathrm{id}=50080109$

BOLINA, C. C. Maturação fisiológica da semente e determinação da época adequada de colheita do feijão (Phaseolus vulgaris L.). Revista Cientifica Linkania Master, v.2, n.3, 2012. http://linkania.org/master/article/view/78/50

BOTELHO, F.J.E.; GUIMARÃES, R. M., OLIVEIRA, J.A.;EVANGELISTA, J. R. E.; ELOI, T. A.; BALIZA, D. P. Desempenho fisiológico de sementes de feijão colhidas em diferentes períodos do desenvolvimento. Ciência e Agrotecnologia, v.34, n.4, p.900-907, 2010. http://www.scielo.br/scielo. php?script=sci_arttext\&pid=S1413-70542010000400015

BRAGA-JUNIOR, J. M. Maturação, qualidade fisiológica e testes de vigor em sementes de mamona. UFP, Areias. 2009. 62p. http://www.livrosgratis. com.br/arquivos_livros/cp085203.pdf

BRASIL. Ministério da Agricultura, Pecuária e Abastecimento. Regras para Análise de Sementes. Ministério da Agricultura, Pecuária e Abastecimento. Secretaria de Defesa Agropecuária. Brasília: MAPA/ACS, 2009. 395p. http:// www.agricultura.gov.br/arq_editor/file/2946_regras_analise_sementes.pdf

CARDOSO, M. J.; RIBEIRO, V. Q. Desempenho agronômico do feijãocaupi, cv. Rouxinol, em função de espaçamentos entre linhas e densidades de plantas sob regime de sequeiro. Revista Ciência Agronômica, v.37, n.1, p.102-105, 2006. http://www.redalyc.org/articulo.oa?id=195317425018

CARVALHO, N. M.; NAKAGAWA, J. Sementes: ciência, tecnologia e produção. 4 ed. Jaboticabal: FUNEP, 2000. 588 p.

DAVID, A. M. S. S.; ARAÚJO, E. F.; MIRANDA, G. V.; DIAS, D. C. F. S.; GALVÃO, J.C. C.; CARNEIRO, V. Maturação de sementes de milho-pipoca. Revista Brasileira de Milho e Sorgo, v.2, n.3, p. 121-131, 2003. http://rbms. cnpms.embrapa.br/index.php/ojs/article/view/78/79

DUTRA, A. S.; TEÓFILO, E. M.; MEDEIROS, FILHO, S.; DIAS, F. T. C. Qualidade fisiológica de sementes de feijão caupi em quatro regiões do estado do Ceará. Revista Brasileira de Sementes, v.29, n.2, p.111-116, 2007. http://www. scielo.br/scielo.php?pid $=$ S0101-31222007000200015\&script $=$ sci_arttext

EDMOND, J. B.; DRAPALA, W. J. The effects of temperature, sand, soil, and acetone on germination of okra seeds. Proceedings of the American Society for Horticultural Science, v.71, p.428-434, 1958.

ESKANDARI, H. Seed quality changes in cowpea (Vigna sinensis) during seed development and maturation. Seed Science and Technology, v.40, n.1, p.108-112, 2012. http://www.ingentaconnect.com/content/ista/ sst/2012/00000040/00000001/art00012

FARIA, M. A. V. R.; PINHO, R. G. V.; PINHO, E. V. R. V.; GUIMARÃES, R. M.; FREITAS, F. E. O. Qualidade de sementes de milho colhidas em diferentes estádios de maturação em duas épocas de produção. Revista Ceres, v.52, n.300, p.293-304, 2005. http://www.ceres.ufv.br/ceres/revistas/ V52N300P02305.pdf 
FAO - Food And Agriculture Organization Of The United Nations. 2009. Crops: Cow peas, dry. Fao Stat. Avaliable at: http://faostat.fao.org/site/567/ DesktopDefault.aspx?PageID=567\#ancor Acessed on: Feb.10 ${ }^{\text {th }}, 2014$.

FREIRE-FILHO, F. R.; RIBEIRO, V. Q.; BARRETO, P. D.; SANTOS, A. A. Melhoramento Genético. In: FREIRE FILHO, F. R.; LIMA, J. A. A.; RIBEIRO, V. Q. (Eds). Feijão-caupi: avanços tecnológicos. Brasília: EMBRAPA, 2005. p. 487-497.

KERMODE, A. R. Role of abscisic acid in seed dormancy. Journal of Plant Growth Regulation, v.24, p. 319-344, 2005. http://link.springer.com/ article/10.1007\%2Fs00344-005-0110-2

MARCOS-FILHO, J. Fisiologia de sementes de plantas cultivadas. Piracicaba: FEALQ, 2005. 495p.

ROCHA, M. M.; CARVALHO, K. J. M.; FREIRE FILHO, F. R.; LOPES, A. C. A.; GOMES, R. L. F.; SOUSA, I. S. Controle genético do comprimento do pedúnculo em feijão-caupi. Pesquisa Agropecuária Brasileira, v.44, n.3, p.270-275, 2009. http://www.scielo.br/scielo.php?script=sci arttext\&pid $=$ S0100-204X2009000300008
SILVA, V. P. R.; AZEVEDO, P. V.; BRITO, R. S.; CAMPOS, J. H. B. C. Evaluating the urban climate of a typically tropical city of northeastern Brazil. Environmental Monitoring and Assessment, v.161, n.1-4, p. 45-59, 2010. http://www.ncbi.nlm.nih.gov/pubmed/19184489

TEIXEIRA, I. R.; SILVA, G. C.; OLIVEIRA, J. P. R.; SILVA, A. G.; PELÁ, A. Desempenho agronômico e qualidade de sementes de cultivares de feijão-caupi na região do cerrado. Revista Ciência Agronômica, v.41, n.2, p.300-307, 2010. http://www.scielo.br/scielo.php?script=sci arttext\&pid=S1806-66902010000200019 